高温時の鉄骨柱の座屈温度に関する実験

正会員 ○高 野 孝 次* 同 吉 田 昭 夫*

\section{1. 目 的}

本研究は，細長比の異なる数種の鉄骨柱について載荷 加熱武験を行い，さきの耐火試駼結果（注 1,2） と総合乙 て, 鉄骨柱の座屈許容温度を求めたものである。

\section{2. 実験方法}

試験体の鉄骨柱は $\mathrm{H}-100 \times 100 \times 6 \times 8, \mathrm{H}-150 \times 150 \times$ $7 \times 10$ 抢よび $\mathrm{H}-200 \times 200 \times 8 \times 12$ の 3 種類である。ま た，常温に括ける座屈試験を各 1 本行った。耐火被覆 は, メタルラス巻吹付石綿リンペット（此重約 0.3）厚 $10 \mathrm{~mm}$ または $20 \mathrm{~mm}$ である。

大形耐火炉で, 柱四周から加熱しながら所要の定荷重 を載荷した。加熱は JIS A 1304 の標準加熱。鉄骨柱に 座屈を生じた直後季で加熱した。変形の測定は，压縮試 験機ラムの上下降の距離を測定, 柱全長の伸びを求め た。

\title{
3. 実験結果
}

各試験体の鋼材温度と変形量の測定結果を第 1 図招よ

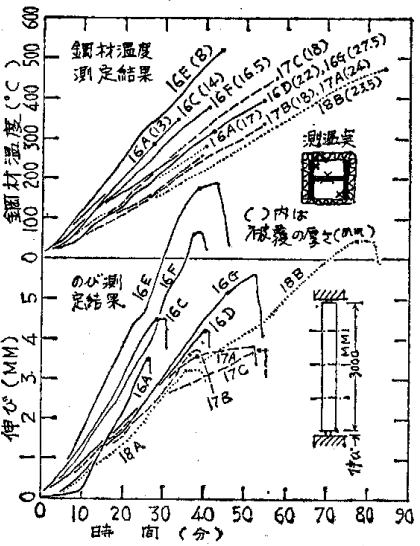

第 1 図 実験結果

$\frac{\sigma_{k t}}{\sigma_{k 0}}=\frac{E_{t}}{E_{0}}$ び第 1 表に示す。

高温下の鋼材の弾性係 数呿よび降伏点は常温時 の $E_{0}, \sigma_{y_{0}}$ から $E_{t}, \sigma_{y t}$ 飞低下し，これそしたが 口て座屈応力度 $\sigma_{k_{0}}$ が $\sigma_{k t}$ 飞低下する。座屈時 の温度と存在応力度加ら Euler 式招よび Johnson 式で下式に上り座屈時の $E_{t} / E_{0}$ 拓よび $\sigma_{y t}$ を求め た。

第1表 試験体および実験結果

\begin{tabular}{|c|c|c|c|c|c|c|c|c|c|c|c|c|c|c|c|c|c|c|}
\hline \multirow{2}{*}{$\begin{array}{l}\text { 試 䮜 } \\
\text { 番 }\end{array}$} & \multirow{2}{*}{$\begin{array}{l}\text { 体 } \\
\text { 号 }\end{array}$} & \multirow{2}{*}{ 鉄 骨 } & \multicolumn{2}{|c|}{$\begin{array}{r}\text { 石綿吹付愿 } \\
\quad(\mathrm{mm}) \\
\end{array}$} & \multicolumn{2}{|l|}{ 載 } & \multirow{2}{*}{$\begin{array}{l}\text { 妿 蓺 } \\
\text { 時 分) } \\
\text { (分) }\end{array}$} & \multirow{2}{*}{$\begin{array}{l}\text { 座 屈 } \\
\text { 時 分) } \\
\text { (分) }\end{array}$} & \multicolumn{8}{|c|}{ 座屈時の鋼材温度 $\left({ }^{\circ} \mathrm{C}\right)$} & \multirow{2}{*}{ 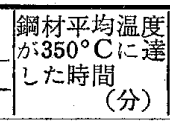 } & \multirow{2}{*}{$\begin{array}{l}\text { 伸 び } \\
(\mathrm{mm})\end{array}$} \\
\hline & & & 計画 & $\begin{array}{l}\text { 零 测 } \\
\text { (平均) }\end{array}$ & $\begin{array}{l}\text { 苟重 } \\
(t)\end{array}$ & $\begin{array}{l}\begin{array}{l}\text { 存在痣力 } \\
\left(\mathrm{kg} / \mathrm{mm}^{2}\right)\end{array} \\
\end{array}$ & & & $\begin{aligned} \text { 中 } \\
\text { 平均 }\end{aligned}$ & 最低 & 最高 & $\begin{array}{l}\text { 部 } \\
\text { 籁园 }\end{array}$ & 全 & 最低 & 最高 & $\frac{\text { 体 }}{\text { 範再 }}$ & & \\
\hline \multirow[t]{6}{*}{16} & A & $\mathrm{H}-100$ & 10 & 13 & 28.6 & 13.06 & 27 & 26 & 286 & 280 & 291 & 11 & 295 & 275 & 315 & 40 & 31 & \\
\hline & B & 断面積 & 10 & 14 & 25.4 & 11.61 & 33 & 28 & 290 & 268 & 308 & 40 & 295 & 270 & 315 & 45 & & 9. \\
\hline & C & .90 & 20 & 23 & 30.6 & 13.97 & 42 & 40 & 304 & 293 & 310 & 17 & 330 & 295 & 345 & 50 & 39 & \\
\hline & D & & 10 & 8 & 20.6 & 9.54 & 44 & 38 & 504 & 460 & 518 & 58 & 485 & 460 & 515 & 55 & 4 & 5. \\
\hline & E & $\lambda=121$ & 20 & 16.5 & 26.0 & 11.87 & 41 & 37 & 334 & 320 & 340 & 20 & 335 & 325 & 340 & 15 & & 11. \\
\hline & $\mathrm{F}$ & & 20 & 27.5 & 27.0 & 12.33 & 54 & 45 & 328 & 300 & 368 & 68 & 320 & 300 & 370 & 70 & & 10. \\
\hline \multirow[t]{3}{*}{17} & A & & 20 & 24 & 65.0 & 15.19 & 55 & 37 & 218 & 208 & 250 & 42 & 230 & 215 & 255 & 40 & & \\
\hline & B & & 10 & 18 & 70.0 & 17.44 & 40 & 36 & 241 & 230 & 260 & 30 & 240 & 225 & 255 & 30 & $\ldots: \cdots$ & \\
\hline & $\mathrm{C}$ & $\begin{array}{c}\mathrm{cm}^{2} \\
\lambda=80\end{array}$ & 10 & 18 & 48.0 & 11.96 & 58 & 54 & 416 & 398 & 448 & 50 & 415 & 400 & 450 & 50 & 38 & \\
\hline \multirow[t]{2}{*}{18} & A & $\begin{array}{r}\text { H-200 } \\
63.53\end{array}$ & 10 & 17 & 40.0 & 15.74 & 40 & 35 & 241 & 230 & 262 & 32 & 255 & 230 & 270 & 40 & $\cdots: \cdots$ & 6.26 \\
\hline & B & $\begin{array}{c}\mathrm{cm}^{2} \\
\lambda=60\end{array}$ & 20 & 23.5 & 84.3 & 11.17 & 84 & 78 & 442 & 422 & 480 & 58 & 457 & 430 & 490 & 60 & 52 & 12.7 \\
\hline
\end{tabular}

$$
\sigma_{y t}=\frac{2 \pi^{2}}{\lambda^{2}} E_{t}\left(1-\sqrt{1-\frac{\lambda^{2}}{\pi^{2} \cdot E_{t}} \sigma_{k t}}\right)
$$

その結果を $E_{t} / E_{0}, \sigma_{y t} / \sigma_{y 0}$ として既往の材料試験資料 （注3）と比較すると第 2 図括よび第 3 図のようである。

鋼構造計算規準では，降代点を短期許容応力度の基準 とし，その $2 / 3$ を長期許容応力度としている。したがっ て火災時の鉄骨柱の鋼材の降伏点が常温時の $2 / 3$ より低 下寸ると長期䛨容応力度より小となり危険である。座屈 許容温度は少くとも平均で $350^{\circ} \mathrm{C}$ をとることがのどま しい。

謝辞 本研究は鋼材クラブ防火委員会（主査碓井憲一 氏）の研究費飞よるものであり，武蔵工大卒業生今井聖 一・伊藤正信・田口栄一・山上弘明の 4 君の協力を党 た。深く感謝の意を表します。

*東京都建築材料検查所員

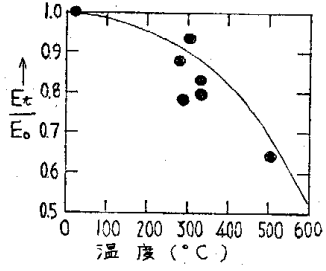

第 2 図 弾性俰数の低下

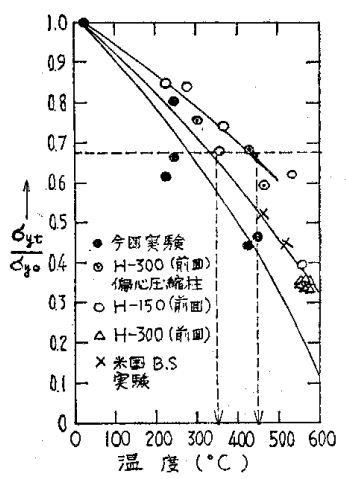

第3 図 降伏点の低下
（注 1）高野・吉田「各種防火被覆をほどこした鉄骨柱の耐火試 駼結果について」建築学会論文報告 第89号 38 年 9 月

（注 2）高野・吉田「軽量被覆鉄骨柱の耐火性能に関する研究」 火災学会 学術講演会 38年11月

（注 3 ）高野「高温下における鋼材の降伏点およびヤング係数の 低下について」建築学会関東支部33回発表会 38年1月 